\title{
CULTURAL MATRIX OF RUSSIAN STATE POWER (SPIRITUAL - IDEOLOGICAL FOUNDATIONS)
}

\author{
Ph.D., V. N. Pervushina1 Ph.D., V.S. Ostapenko² Ph.D., L. M. Savushkin³ \\ DSc, E.M.Leshchenko ${ }^{4}$ \\ ${ }^{1}$ State University of Justice, Central branch, Voronezh, Russian Federation, email \\ veravalen47@yandex.ru \\ ${ }^{2}$ State University of Justice, Central branch, Voronezh, Russian Federation, email ostapenko- \\ vl@yandex.ru \\ ${ }^{3}$ State University of Justice, Central branch, Voronezh, Russian Federation, email \\ savushkin.lieonid@mail.ru \\ ${ }^{4}$ Russian Academy of National Economy and State Service under President of Russian Federation, \\ Voronezh, Russian Federation, email l.e.m@bk.ru \\ ${ }^{*}$ Corresponding author
}

\begin{abstract}
The article deals with the spiritual and ideological foundations of the Russian state power. The main idea of the work is to recognize the defining meaning of cultural determinants in the formation of the specific nature of Russian state power. The first cultural universal includes recognition and understanding of Christian universalism literally. It is reflected in the notion of "Holy Russia" and its other form: "Moscow - the third Rome". This notion is of the space content and the "super - ethnic", having served as a basis for formation of the Imperial ideology subsequently. In the social space it has led to a weak link between the government and the people. It was formed as if two areas: state power and people. With a weak connection between these two areas, it was possible to reach to the authorities only on the basis of radical social practices. And there is the second cultural determinant. Russian Holiness was an antinomy of light and darkness, a dualistic understanding of the world. There was no middle ground between them. And, therefore, there was no place "legalized" for the state and secular authorities. They were above or below the social world. Taking into account the absolutization of the moral-ethical dimension of Russian culture (the Orthodox civilization adheres to the spiritual side only), the power fell out of the sphere of rational, was not mediated by legal discourse and was considered to be as torments of conscience. In society it led to a weak legitimating of state power and legal culture. The recognition of the holiness of the secular authority under Peter the Great has led to the formation of "paternalistic" matrix of Russian state power. In the light of this matrix the "Father of the Fatherland", the autocrat, was responsible for everything. This paternal model of power is going on to exist nowadays.
\end{abstract}

Keywords: authority, power, hype sacredness, cultural determinants, "The Holy Russia", "Moscow - the third Rome", the autocracy, the Fatherland, the Imperial ideology, the Orthodox civilization, legal discourse, tolerance 


\section{INTRODUCTION}

The purpose of this article is to analyze the spiritual foundations of the Russian state power. Such an approach allows revealing of attributes and characteristics of Russian state power in the fullest extent. The researchers of home and foreign literature viewed the nature of Russian state power in the socio-economic (Yu. Piivovarov, R. Pipes) or in socio - psychological terms (N. Rozov). For the sake of justice, it should be noted that the patrimonial nature of Russian state power long before of $Y u$. Pivovarov and R. Pipes were noted by Russian researchers V. Klyuchevsky and P. Milyukov. The above modern researchers pointed out some fundamental characteristics of state power in Russia - the authoritarian constant, the personified nature of power (Yu. Pivovarov), the imitation of democracy (A. Akhieser, I. Klyamkin, I. Yakovenko), the archaism of the socio-cultural space (V. Buldakov). But the question remains: why does power in Russia have such a nature? And link of power and property it's not the only essential property of Russian power. For this connection you need to find a cultural justification. Therefore, we need theoretical reflections on the particularities and trends of Russian spiritual culture, which formed this type of state power and this type of ideology. The analysis of the literature (there is not so much research) on the nature of Russian state power shows that the phenomenon of power is being regarded and analyzed in modern literature mainly in political, socio-psychological and sociological terms. It leads to the actualization of one side of state power and the proliferation of one matrix of power, attributive-relational-activity (authority). We need a philosophical reflection of the phenomenon of state power, taking into account the complexity of this phenomenon. It allows in understanding of trends and experience of the Russian spiritual tradition. These issues concern the nature of Russian state power directly. For solving these problems it is necessary to define the concept of power. M. Weber is known for his regarding power and introducing its distinction between power (Macht, Power) and power-domination (Herrschaft, Authority )(1, pp. 511-545,628-644). Weber's power sociology is based on his understanding of social action and the typology of social action.

Macht -power manifests itself in the ability of one (some) to influence on the other (others), so called the power side and the subordinate one. The power side achieves submission to its will. The subordinate side is forced to do something that it would never do otherwise, obeying the will of the ruling side.

In society Weber's formula of Macht-Power solves the problem of social order exclusively by extreme, radical means: armed or class conflicts. These methods of decision of conflict generate permanent and long-term instability.

Herrschaft-Authority is the legitimate power, generates voluntary consent of the governed, recognized by them. Weber proposed his typology of "ideal types "of legitimate domination, coinciding with the analysis of social action- behavior. He singled out the traditional, charismatic and rational-legal legitimization of power. Traditional legitimate domination is based on the belief in the legality and sacredness of the existing power and social order. This type of domination is adequate to the traditional type of action and corresponds to Gemeinschaft. Another type of legitimate domination - charismatic, unlike traditional, relies not on the power of habit, but on an extraordinary, emotionally colored attitude of devotion and faith towards a charismatic leader. The charismatic type of legitimate domination actualized the dynamism of traditional society (affective behavior was adequate to this type of domination), relied, as well as the previous type of traditional legitimacy, on personal relations between the powers side and subordinate one. And finally, the rational-legal type of legitimate domination (it is based on the purpose-rational action). It is based on the formal legal principle: all are subject not to the individual, but the established laws (this type of legitimacy operates in Gesellschaft). This principle, according to Weber, contributed to the development of modern capitalism within the framework of formal rationality and the formation of bureaucracy as a "technically ideal" type of legal domination. If we use the typology of $\mathrm{M}$. Weber, the paradigm of Russian state power is adequate to the synthesis of the traditional and charismatic types of domination defined as Macht, Power.

The authors for the analysis of the nature of the Russian state power regard the basic blocks of traditional philosophical and cultural discourses: historical- cultural, historical - philosophical and logical methodological, used as a substrate for the construction of the integral phenomenon of Russian state power. Using the terminology of medieval philosophy, we can say that the power in the Russian culture is the absolute term, but the strength, influence, domination, management, control are connotative ones, directly or indirectly revealing the nature of power. The critical reconstruction of the history of Russian spiritual culture reproduces the ontological and social points of support of the Russian state power, makes it possible to explore the existence of power, to discover its philosophical and conceptual basis (recognition of the sacredness of secular state power, this is not in any culture). Philosophical and cultural reflection allows us to view power in its conceptual architectonics: ontological, anthropological, historical- cultural, scientificpositive approaches. 
So, the nature of Russian state power is analyzed in the article in a very broad context - as a cultural, philosophical -anthropological problem. The work focuses on the main attribute of the Russian spiritual culture - universalism, resulting from such a value-semantic understanding of life (generating from the universal understanding of Christianity by Orthodoxy and reflected in the concept of "hyper sacredness"), concentrated in the notion of "Holy Russia", which later took another historical form of "Moscow - the third Rome, the fourth is not to be". This form has recognized the equality of all nations before God, so it was the notion of super-ethnic, contributed to the formation of the Imperial ideology. It should be noted that the characteristic features of Russian culture were brilliantly disclosed by researchers such as N. Berdyaev, K. Leontiev, G. Fedotov, S. Averintsev, A. Panchenko, V. Toporov, Yu. Lotman. In the works of these authors the influence of cultural universals on the nature of the Russian state power noted, but some cultural determinants are currently difficult to recognize to be the true (N. Berdyaev, G. Fedotov).

Hyper sacredness was the basis of the notion of "Holy Russia", assumed the antinomy of light and darkness and did not include a separate space for the state and, therefore, state power. The state power was either above the world or below it. The power was not mediated by contractual legal relations.

Finally, the proposed theory of cultural - spiritual universals and its role in the formation of Russian state power determines its being in the social space:

1. Universalism has led to a weak link between ethnos (ethic groups) and state power. The separate space of power and the separate space of people have formed. People could influence on the state power mainly by radical social practices.

2. The idea of "secular Holiness", proclaimed by Peter the Great, "Father of the Fatherland", has led to the formation of the cultural matrix of Russian power - "paternalistic", existing up to this day.

3. The absolutization of moral - ethical issues in Russian spiritual culture established cultural background of tolerance. The nature of Russian tolerance means patience for evil: it had no boundaries (Russia is a multinational country) and a weak legal culture. The Russian law was not designed to be used, "either a threat or a new hope" (A.Panchenko). Until now federal laws are not always a decree for local authorities.

4. The ideology of the Russian state, which began to form since the time of Ivan 111, acquired an autocratic and liberal character simultaneously. In the mentality of the people, power is still associated with the autocrat, the "Father of Fatherland" and the ideas of liberalism were carried out from above, by the power itself.

5. The Imperial ideology of the Russian state power responded to the multicultural, multi-ethnic, multiconfessional nature of the Russian state.

The work is written at the level of general theory and does not fit into the narrow scientific space of the applied, empirically oriented research methods such as experience, the analysis of data, and so on. The further presentation and study of this issue will require some theoretical reflections and analytical comparative approach to solve the problem of nature of Russian state power.

Usually in foreign literature (2, p. 36) it is customary to search for the origins of totalitarianism in Russia in the very nature of its power. In our opinion, it is more correct to put the issue of the specific type of state power in Russia. In order to answer this question, it is necessary to identify the spiritual basic components of Russian culture, which led to the formation of this special type of Russian state power first of all.

Let us turn to the spiritual origins of Russian culture. It was known that Byzantium, spiritual practice of Hesychasts played a special role in formation, national world perception and self-consciousness of Russian culture [3]. But Russia did not borrow everything automatically. So, there was a refusal of justice of the Roman-Byzantine type because the Russian tradition was broken: to take from the offender money and a sin to execute "enemies of the sovereign" ([4, p. 211).

Another feature of Russian culture was the acceptance and understanding of Christianity with its universalism literally. This was reflected in the notion of "Holy Russia", a cosmic category "containing both the old Testament Eden and the Evangelical Palestine". S. Averintsev drew attention to the fact that "Holy Russia" was not localized in space: it differs only by two attributes - to be the whole world, including even Paradise, and to be the world under the sign of true faith (4, pp. 216-217).

The notion of "Holy Russia" is essentially a soborny (collective religious consciousness) image of Holiness. V. N. Toporov notes hyper sacredness of the ancient traditions: 1) everything must be in principle sacred, torn from the power of the evil beginning and will be returned to the original state of wholeness, chastity, purity ...;2) there is a united universal purpose ("the super-goal"), the most cherished desire -"the Holy Kingdom" ...;3) there is a strong and actual hope that holy condition can be approached in space and time, 
here and now (Liturgy is already an image of this condition, hence a desire to prolong the liturgical time, on the one hand, and inattention to the profane, on the other hand (5, pp. 8-9).

In the" Word of Law and Grace» Ilarion wrote about two epochs of historical development - the era of Law and Grace. The latter is characterized by the moral responsibility of the individual, the equality of all people before God. Therefore, the notion of "Holy Russia" is a notion of super-ethnic. The Romanesque-Moscow state is open to those who accept its faith. N. Berdyaev noted that in the Russian element there was some national unselfishness, sacrifice, unknown to Western people. He pointed out "the super national, all-human spirit of the Russian people." Russia is called to be the liberator of Nations (6, pp. 13-14).

Law and Grace are a united and common space, fixing a different attitude to space and time. Infinity is actualized in the space of Grace, it has no limit. The space of law is limited in time and space. For Christ and his deed no law is needed. Salvation through law is impossible! The religion of law divides people into pure and impure by virtue of compliance of external norms (Pharisees and scribes). There is another worship of the Father in the spirit, and the truth is freedom of the infinite. The reverse side of this universalism was "a weak development of the motive of natural link between the ethnic group and the state (5, pp. 306,438)". At first we are Christians, and then-Russians.

The idea of Holiness in the Russian version generates neglect of this world, and the hope exclusively on another Kingdom, the rejection of constructive reality and faith in salvation in passive ways and maximalism, going out of control, attachment to extremes (salvation through sin), removed by repentance and selfish aspect of Holiness. "Universal responsiveness" is characteristic of Russian soul. Russian Holiness is more and more in the ways of martyrdom, austerity, foolishness, reclusion, than hard work, constantly logical, purposeful illuminated and lighted by logos name meanings. Hence, a breakthrough in the spiritual sphere - literature, art, creations of national spirit - from the idea of a peasant world to the hope of finding of the Kingdom of God, with which this world is related to, here and now than the deeds of material and economic values, ... and specific social institutions ... . (5, pp. 604, 606, 722). Humility corresponds to an ideal norm. The true height is below, in humiliation, without being humiliated, you will not rise. Humiliation is the necessary condition for Christian life.

S. Averintsev, analyzing and comparing the understanding of Holiness in the Byzantine and Russian traditions, notes their general meaning and at the same time the difference. Russian understanding of Holiness more corresponded to "Patriarchal foundations of life", "did not transform into mental tone", differed by "amazing sincerity and spontaneity, as could be nowhere." Unlike Catholicism, the space of light and darkness was not mediated by civilization.

In Catholicism, the question was put about correlation «between Holiness and social civility as a problem of moral theology" (7, p. 343). An individual space was connected with others by relations of the contract. In Western theology the law of justice is a necessary condition for the existence of the social world, the lower floor, and, accordingly, the upper floor - the "law of love". Contractual relations have a sanction in God, without them it is impossible to protect a person from sinfulness of his/her own and of alien one. In Catholicism instead of the dualism of light and darkness the sphere of the natural is pointed out, which is also under the power of God, this is the state power. Catholic theology tries to reveal the boundaries of this sphere. This medieval principle of acquiring power according to contract is in perfect agreement with the doctrine of metaphysics, that only the individual is a real essence (8, p. 210). In "Summa theologica" and in comments to the "Politics" of Aristotle T. Aquinas justifies the basic principles of scholastic social philosophy concerning the nature of the state. The state exists for the benefit of its citizens and not vice versa. This concerns to any collectivity, be it a family, a village, a Kingdom, an Empire. T. Aquinas notes that every human being has value, but he/she cannot realize the true benefits of life - knowledge and love being alienated. And this is the reason for existence of society. For a person to live in any type of sociality is a natural necessity. And this sociality, including the state, should help the citizen to become a good person. It is the highest duty of state. Human being realizes his/ her rights, which state cannot encroach upon, so far as their legitimacy derives from the value of individual by his/herself. Declaration of human rights in the X111 century includes the right to preserve their lives, the right to marry and bring up children, the right to develop their intelligence, the right to education, the right to truth, the right to live in society $(8, p .190)$. From the ethical point of view scholasticism justifies the value of the individual before state power. From metaphysical point of view only the human person is a true real substance. Any social entity, including the state, is not a real one, but a group of human beings whose lives are based on participation in activities for the common good.

In contrast to the Catholic theology Russian Holiness was an antinomy of light and darkness, fearfulness and meekness, two poles of united antinomy, lying in the very foundations of Holy Russia. This determines both Russian consciousness and Russian history. Its hidden influence does not stop when the Orthodox tradition 
is not remembered about $(7$, p. 348).

The dual understanding of the world in Russian culture is nowhere is «felt so sharply as in the question of power. God and the Antichrist come right up close, without any buffer territory between them; everything that seems to be earth and earthly is actually Paradise or Hell; and carrier of power stands exactly on the border of both kingdoms. This means that he has a special responsibility before God - such a trivial truth is known to everybody. The power by itself, at least the autocratic power, is something that is either above the human world, or below it, but in any case, as it is not incoming in this world. Blessing here is difficult to separate from curse. The Orthodox civilization is entirely on the side of spirit. According to S. Averintsev, for Russians antinomies, included in power over people, are in the phenomenon of power by itself, remained from century to century ... it is not a problem for reason, as the torment for conscience. The Russian monarchy arises from Patriarchal relations (Byzantine rationality and the Russian soul (sufferings are justified the existence of state power (the murder of Boris and Gleb) (9, pp. 355, 220).

With the fall of the Byzantine Empire the Moscow Kingdom represented itself as the successor of the historical mission of Byzantium. This idea was formulated by the elder (starets) of the Pskov monastery Philotheus - "Moscow is the third Rome, and "the fourth would not be ". The Russian Kingdom until the second coming of Christ will be a carrier and guardian of universal Christianity. This is another historical form of ancient Russian ideal of Holy Russia.

To understand the evolution of spiritual and ideological foundations of Russian state power, let us turn to the historical analysis of Moscow Kingdom, the state under Peter the Great, the Soviet state and modern Russia.

The formation of Russian national ideology begins since Ivan 111. It was he, who determined the idea of pan-Russian "the whole Russian land, Kiev and Smolensk and other cities - from our ancestors are our patrimony..." (10, p. 48). The idea and practice of monarch power was formed since the reign of Ivan the Terrible. Ivan the Terrible was first to be crowned, he was a legitimate tsar, before the title of tsar was used in Russia in relation to the Byzantine Emperor and the Khan of the Golden Horde. God is a tsar of heaven, and a tsar is an earthly God." Ivan the Terrible gave preference to the first person of the Christian Trinity-God the Father, Savaof, terrible and punishing God. Savaof is an inexorable law, and on earth He is embodied by sovereign. At the same time with God the model for the tsar could serve Michael the Archangel. This is not only a Moscow tradition. This is a universal tradition (11, pp. $23-.26)$. According to A. M. Panchenko, the doctrine of Holiness of tsar power was rejected by Russian public opinion. The people's conception of imposture was opposed to conception of Ivan the Terrible. Imposture is a people's shell of riot. Two types of imposture are denoted - false Dmitry and the peasants ' Tsar-father (11, pp. 28-30). The collapse of authority of secular power was accompanied by the collapse of the spiritual one- heresies appeared (10, p. 61).

Emerging theory of autocratic power was in contradiction with mood of the former princes, boyars. The nobles demanded the right of "council" in public affairs, and in fact advocated the dual power. Ivan the Terrible in correspondence with Kurbsky noted the cause of death of kingdoms - "tsars were obedient to eparchies and sinclites"; ... Truly, "the earth is ruled not by judges and voevodes, not by hypatos and stratigs, but by God's mercy, all the saints' prayers, blessing of our parents ', and finally, by us, our sovereigns" (10, p.73). Boyars spoke for the dual power-tsar and the elected Rada. Nobles on feeding stood between tsar and people. It was necessary to eliminate suspicious mediators between tsar and people. Ivan the Terrible was the first to establish the practice of direct communication with people from the place of execution and religious processions at the same time (lobnoy place). To appeal directly to people is a reception of Ivan the Terrible... (10, p. 76).

The closest practical application of this theory was an attempt to eliminate "grandee - feeders" from management, court and financial fees. The distribution of gubnoy (local self-management) and introduction of Zemstvo, no doubt, was quite conscious product of this autocratic-democratic ideology, by $P$. Milyukov's definition (10,p. 81). In the interests of local nobility first Zemskie Sobors (councils) were also convened, but they solved the issues of "simple examination" (on official validity at the moment). Having stood for the protection of the interests of one class, the Moscow government has prepared a new opposition (peasants and serfs). Ivan the Terrible was the first to present a democratic-monarchical program. He understood under the democracy protection the interests of the serving "army". It received the right to freely dispose of serfdom and a significant share in the benefits of the established bureaucratic regime.

The state under Peter the Great as it was. The Old Russian ideal of Holy Russia under Peter 1 was transformed into the idea of "secular Holiness" (especially planted under Nicholas 1, the practice of isolationism was implemented, having reflected in the ideology -" Autocracy, Orthodoxy, and Nationality"). The ideas of" secular Holiness "were quite natural for the tops that have broken with" Holy Russia", gradually 
penetrated into the people. It defined and controlled of applicants for a place on the Russian Olympus... The people rejected the "blessed "liberators".... in full agreement with the national tradition. People in the era of "stopping" of Holiness have chosen poets. Their books, like the works of the Church fathers, are not subject to aging and retain the quality of teaching after decades and centuries. This is a purely Russian situation, and we would add tradition ... in our calendar month there are plenty of Holy princes, but no (!) holy tsar. And we are being told that the Russians are slaves ... (11, p. 392). Peter the Great took the title "Father of the Fatherland" in 1721, before this title could only be applied to arkhirey and especially to the Patriarch. Peter has led the Church and declared himself as a Patriarch. The church was deprived its autonomy and made subordinate to the state. "Father of the Fatherland" is an ideal and enlightened monarch, the civilizer, the guardian of national efforts and national creativity (Pater Patriae) $(11$, p. 72 .). "The concept of Fatherland had family- kin connotations and represented a paternalistic community of kin relationships, while Pater Patriae was as a trustee and guardian of Russia". Enlightenment split the state-Fatherland to society, understood as a set of private citizens and the state as a mechanism of legitimate power. The separation of the state from the person of the sovereign was carried out on the order of the autocrat, who controlled this state completely (12, pp. 30, 37-38). Autocratic will is the main driving force of the Russian state, and therefore, no matter how much is said about the public good, which the sovereign and the people together should strive for, the idea of a common "Fatherland" for everybody is spread by the order of the sovereign, the absolute master in his ownership, so to argue with the autocrat had been stopped still under Peter the Great. Under Peter the Great the foundations of the so-called "secular Holiness" were laid. Such a phenomenon is not in the West. In Russia foundation of "secular Holiness" led to the gap between the secular and spiritual culture (11, p. 393). In socio-political practice "strictly bureaucratic system" has been formed in XY111 century. The newly established order of management placed the state in the hands of an all-powerful bureaucracy, over the abuses of which no real control was possible. Under Peter the First "everything was possible, and nothing was obligatory, except for the next order of the reformer" (10, pp. 172173). In the interval between the disintegration of the boyars and the domination of the nobility, between $\mathrm{XY} 11$ and $\mathrm{XY} 111$ century, bureaucracy was the only ruling class. Peter the First ceased to convene the Boyar Duma, instead of it a new body (Blizhnya kanzelyaria) was formed. He appointed there his associates, whose activities were tightly controlled. Peter the First created fiscal bodies that control the work of the administration at all levels. We saw how the nobility at the very moment of its victory over the boyars and Cossacks, voluntarily gave a ruling role to the bureaucracy, and refused from the permanent control over it, which could give Zemsky Sobor to the nobility. The people responded with riots (cut voevodes, beat nobles and landowners). By the end of $\mathrm{XY} 11$ century Russian bureaucracy essentially becomes a caste and takes on "oligarchic shade" (P. Miliukov). Peter's reforms, at all costs, which imposed on them the character of the era and the personality of the tsar, has solved national problems, having created a state providing Russia two hundred years of existence in a number of major European powers and one of the most brilliant cultures in the history of human civilization. For Peter the Great public service acquired almost religious significance of grandiose, continuous Liturgy in the temple of State. The work was his prayer. It is through the service it can see themselves as part of the estate (13, pp.19.-21). The Table of ranks (1722) embodied the principle of regularity and served as a kind of social lift. State power, having crushed the Church, did not leave a foundation for the limiting factor. In addition, Peter the First "has inherited a harmful political superstition belief in the creative power of authority and confidence in the inexhaustible national strength and people's patience" from their predecessors (14, p. 330).

The Soviet state. V. P. Buldakov (15, p. 53) notes the break with the past in 1917 and now. It is difficult to agree with this statement. Historical material and works of researchers prove the opposite point of view.

O. V. Kharkhordin, in our point of view, rightly stressed the mainstream in the Russian Christian tradition. The Ideal of Holy Russia was based on the attempt to displace and eliminate the state quiet. It is necessary radically to abolish evil (state) through theosis of human being and the reconstruction of earthly life on the church basis (Dostoevsky, Frank). The Church's influence was reduced to "rebuke, exhort, and excommunicate." The revolution of 1917 has realized Dostoevsky's project (12, pp. 91-92, 94). The atheistic facade, according to Berdyaev, covered the fundamental mechanism of religious dictatorship. Revolution of 1917 can be compared to Puritan reformation in England (revolution of the saints). The Holy Kingdom or the Republic of the saints was established in the Soviet Union after 1917. Soviet Russia has revived the traditional values of pre-revolutionary Russia (a positive role of marriage, pre-revolutionary system of education with classes and evaluations, and so on). The transformation of radical dictatorship of the few saints in the Holy Kingdom, open to everybody is a kind of Bolshevik reformation (12, pp. 119, 147). Bolshevism is more in line with Russian traditions and Russian search for universal social truth, understood maximalistic and Russian methods of control and dominion by violence. Lenin's activity corresponded to two traditions of Russian culture - traditions of the Russian revolutionary intelligentsia in its most maximalist currents and traditions of the Russian historical power in its most despotic manifestations. The Bolsheviks - 
the third phenomenon of Russian great power. The first- Moscow Kingdom, the second-Peter's Empire, the third-Bolshevism, which advocated a strong centralized state. The Bolsheviks created a state "by the methods of ruling was like the old Russian state". The Holy Kingdom (communism) has a great similarity in its spiritual construction with the Moscow Orthodox Kingdom. The power of the third Rome is reminiscent of the 3rd International, to which the features of the third Rome were transferred. "(16, pp. 93.99, 117-118]. V. $P$. Buldakov points out the transformation of revolutionary ritualistic: the demonstrations are like the religious processions, the increasing distribution is received all sorts of "red baptisms"(17, p. 192). The decree of August 10, 1922 provided for the adoption of administrative exile as a preventive measure. The decree gave the security authorities the right, at their discretion, to expel persons involved in revolutionary activities abroad or in certain areas of the Russian Republic for up to three years. It was a revival of the former tsar practice. Lenin was exiled to Siberia for the same period and in exactly the same way as was exiled in 1922 the intellectual elite $(2, \mathrm{pp} .403,404)$. The functions of communism acted as a substitute for religion. There was a cult with its own deity, saints and rituals. The principles of church law were embodied in the activities of the Central Control Commission - not to punish, persuade and exhort, before resorting to the threat of excommunication. The triple logic of the church court is noted in the normative practices of the control Commission of the Russian Communist Party of Bolsheviks and the Orthodox Church (18, pp. 38-39, 42.

Modern Russia (Russian Federation). In Russian Federation the post of President was introduced, it was delicately concealed, that the institution of the presidency prevailed in underdeveloped countries, African and Latin American ones (19, p. 397.) In these countries the President is a dictator. In modern Russia there is a presidential system where the President is above the specialized branches of government (legislative, executive, judicial). The modern state power in Russia, as noted by the researchers reproduces the main particular features of Russian power as such - the growth of security structures, the introduction of the Institute of representatives of the President, clan system, favoritism, the decorative nature of the executive bodies, a return to the tsar attributes and so on (20). As a result, the formation of caste-clan society with very weak social mobility is pointed out in modern Russia as well as imitation of legal-democratic state (21, pp. 19, 459). In modern Russia a "simulation of foreign and alien cultural forms", "masquerade of modernization" has happened (15, p. 83).

What can be concluded? By its cultural nature, the Russian power at all times, from the Tsar, the General Secretary up to the President, remains "paternal" ("otecheskay"), personified. The spiritual and ideological foundation of the Russian state power is "autocratic-democratic" (P. Milyukov), we would define it as an autocratic-liberal. Autocratic-democratic power, no matter how paradoxically the very name sounds, emphasizes the existence of democratic institutions in Russian history - veche, the Council, being the Supreme body of power of city-states in Rus in X1-X111 century.; Boyar Duma, engaged in law-making and the solution of foreign policy issues. It was transformed in the Senate, lasted until the end of $\mathrm{XY} 11$ centuries And, finally, the Zemsky Sobor, acting as an institution of representative authority. It included representatives of all major estates. Its prerogatives were - elections of tsar, the solution of issues of foreign policy, definition of tax policy, internal peace and order. Participation in its activity was akin to service, not a privilege (22). The ideas of liberalism have always come from above, from the authorities. In the pamphlet of I. Peresvetov it was noted the importance of the democratic monarchy, acting as a defender of " autonomy of a person " from the attack of the ruling class on his/her freedom. But, not sharing the interests of the "army" and "civil worldly people", the government has reduced the democratic program to a completely different task - ... for its realization oprichnina and serfdom were needed $(10, \mathrm{pp} .85,373)$. Only in the period of Alexander the Second, starting with Catherine the Great, it becomes possible equalization of civil rights and obligations of different classes and establishing of the same right for all and equal court as well. V. O. Klyuchevsky determined Russian state power in its structure as limited - autocratic. The autocratic power in Russia really was limiting by itself and had different types of legitimation: the sacred (from God), the "democratic" (the Romanovs were elected to the Kingdom by the Zemsky Sobor 1613), and historical continuity (the Romanovs ruled the country for over 300 years), and formal-legal (law on succession to the throne of Paul the First (23, p.181). The basic laws of 1906 fixed all these types of legitimacy in the Constitution and formed another kind of legitimacy: the constitutional- legal. In Soviet times the MarxistLeninist ideology was the limiting factor for state power. In modern Russia, it seems to be no state ideology, but, based on the unchanging nature of Russian state power shaped by centuries of Orthodoxy, the ideology is still clearly visible - the Messianic purpose of Russia (the fight against world evil - terrorism) and for internal use - as always, the ideas of liberalism are combined with the ideology of Slavophilism - Autocracy, Orthodoxy, Nationality (24).

At the beginning of the article we noted the following distinctive attributes of the spiritual foundation of Russian culture, which led to the formation of a particular type of Russian state power: a weak connection between the ethnic group and the state. This led to the parallel existence of the world of power and the world 
of the people. The thought about people was not connected with the thought about the state. The sovereign without the people we could imagine (25, pp. 15, 48 ). Only the Bolsheviks turned the state into a part of everyday life of every citizen. Before that the Tsar was an ideal figure for peasants, embodying divine justice, and state officials were regarded as private individuals whose abuses could be overcome by the Tsar. Officials are personal servants of the tsar, perverting his fair orders (12, p. 45). The parallel existence of power and people led to enforce of reforms from above. No one was interested in the opinion of the people (for example, the fate of the national referendum on the preservation of the USSR). And in this line, reforms in education, medicine, and pension reform, etc, which are being carried out in modern Russia. Has anyone explained the need of reforms? The endless reformation teaches people to endure steadfastly all the experiments of power to survive. And this is in the Russian tradition. "To live according to the gospel" was very profitable-love the superior, helpfulness, servility, not to be beaten, not to be humiliated, so to say, to forestall. The commandment of gospel poverty turns into" clever practical advice" - be content with what it is and remember about the poor. In this flexible morality is a little "Byzantine", it is the "national product of national conditions of existence" - to keep balance" and survive (10 p. 243).

And the second - "not mediated by civilization". It led to weak legal legitimating of the Russian state power and responsibility of state power before society. The paternal form of power, which is clearly manifested at the present time, makes modern lawmaking "similar to children's games" (A.Panchenko). N. Berdyaev wrote about Russia as the most anti-state and anarchist country, in which the Orthodox ideology of autocracy was "the same phenomenon of stateless spirit" (6,p. 10). In this regard, a great deal of work remains to be done to create a state governed by the rule of law, in which the people's good would be given priority.

So, the ideological symbols of Russian life up to $\mathrm{XY} 11-\mathrm{XY} 111$ centuries was the Holiness (priesthood), the Kingdom, Zemstvo (the world). The dominant position in this scheme was occupied by Holiness (5 ,p. 604). At the time of Peter the Great Holiness transferred to state power, the Imperial ideology was formed, which was adequate to the multi-ethnic, multicultural and multi-confessional nature of the Russian state. In Russia in the X-X1 centuries lived 22 ethnic groups, this phenomenon has never been. Hence there is a tolerance. And no matter how we currently try to deny the fact that the Russian Federation does not claim the restoration of the Empire, the existence of numerous ethnic groups (more than 180), inhabiting the territory of modern Russia with different cultural traditions and religious beliefs, brings to life the Imperial ideology and necessity in political practice of the strong centralized power.

Notes

1. V. Klyuchevsky argued that ... neither of feeding nor of the boyars ' estates have not developed Baroni (1987, p. 360). P. Milyukov noted that ... the rights that the Western landowner enjoyed as an independent owner and as a mandatory vassal of his mandatory overlord, our landowner could only get it as an official in the service of the Prince voluntarily elected by him... . Under such conditions the landowner estate could have value not as independent estate, but only as a serving one. Therefore, when the Moscow state began to take shape and grow rapidly, there was no land - owning class that could resist the state as an independent force-with which it had to be reckoned. This class was only an inorganic mass of crude material, which the state used for the construction of its own buildings... the Emperor of all the Russians was only the one (2010, pp. 257-258).

2. In our opinion, the nature of Russian state power cannot be revealed in socio-psychological terms, i.e. analyzing only mentality, particularities of national character, and so on. This is the level of social psychology (hence all the disadvantages of the interactionist approach - it has difficulty dealing with large-scale social phenomena as power is by itself) See, for example, N. Rozov. The Specific Nature of "Russian State Power" (Russian Politics and Law, vol. 50, no.1, 2012, pp. 36-53).

3. The historical forms of Russian power and its evolution are analyzed in detail by Yu. Pivovarov and quite convincingly (Pivovarov, 2014, pp. 176-227). But the works of this author are characterized by excessive emotionality, gluing labels to historical figures - villains or carriers of progress. The scientific approach should include a value-free component. The works of R.Pipes are also distinguished by ideological bias, especially the study "Russia under the Bolsheviks" (R.Pipes, 1997).

4. V. Buldakov and A. Akhiezer recognize incompatibility of historical development of Russia and respectively the power with rationalism and democracy. All the attempts of reforming in this direction return Russia to the archaic, and Russia's natural historical condition is distemper (V. Buldakov, 2007, A. Akhiezer, I. Klyamkin, Yakovenko, 2013). This statement can not be considered justified. Technological and scientific breakthroughs of Russian civilization, the highest spiritual culture refute the thesis of a constant return to the archaic. Any culture has its own layer of archaism (the doctrine of Jung's archetypes). 
5. N. Berdyaev was one of the first to note the antinomy existing in Russian culture: why did the most stateless people create such a huge and powerful statehood, why the most anarchic people are so subjugated by bureaucracy, why does the spirit-free people seem not to want a free life? The Russian thinker pointed out the cause that can hardly be in our time recognized: the correlation of female and male in Russian national character (N. Berdyaev, 1997, p. 13).

6. G. Fedotov, recognizing the universality of the Russian human being and the kenotic essence of people's religiosity, does not focus, however, attention on how these features have an impact on the socio-political space (G. Fedotov. Letters about Russian culture.1938. 260p.).

7. K. Leontiev drew attention to the relationship between liberals and the government. "The liberals have never been in the opposition, they are always the government's party" [Leontiev. Byzantium and Slavs.-M.: DAR, 2003.-274 p.)

8. The deepest analysis of the Russian culture is inherent in the works of S. Averintsev (2005), A. Panchenko (2000), Yu. Lotman (1994). The only thing is that their researches are limited to a specific historical period of time. S. Averintsev's research is limited by the period of the birth of Russian culture, Panchenko's and Lotman's -Peter's time.

9. V. Toporov, having introduced the concept of "hyper sacredness", noted the ideological symbols of Russian life of XY11-XY111 century (Toporov, 1995). Naturally in the future the ideological symbolism of Russia has changed.

10. O. V. Kharkhordin, using the method of genealogical descriptions of M. Foucault, comes to the conclusion about the unchanging nature of power in Russia, its continuity during the Soviet period and the tsarist regime (O. Kharkhordin, 2002, 2011).

\section{REFERENCE LIST}

Weber M.(1991)Selected works. Moscow: Progress.808 p.

Pipes R. (1993) Russia under the Old Regime. M.: "Nezavisimaya Gazeta". - 424 p.

Khoruzhy S.S. Spiritual Foundations of Russian Eldership / htpp: wwwalleluia.rulibrary / reklama2.html Averintsev S. S.(1988) Byzantium and Russia: Two Types of Spirituality. New world. №7. P. 210-221. Toporov V. N.(1995) Holiness and Saints in Russian Spiritual Culture. M. "Gnosis". Vol. 1.875 p.

Berdyaev N. A.(1997) Fate of Russia. Self- knowledge. Rostov / D.: publishing house "Phoenix". 544 p. Averintsev S. S.(2005) Another Rome. SPb.: AMPHORA.366 p.

M. de Wulf.(2014)Medieval Philosophy and Civilization. M. : ZAO Tsentrpoligraf. $253 \mathrm{p}$.

Panchenko A.M. (1992 The Specifics of the Slavic Civilization. Znamya. 9. P. 200-208.

Milyukov P. N. (2010) Essays on the History of Russian Culture. Moscow: ROSSPEN. Vol.2.600 p.

Panchenko A .M.(2000) On Russian history and culture. Saint Petersburg: Azbuka.-464 p.

Kharkhordin O. V.(2011) Main concepts of Russian politics. New literary review.M. - 328 p.

Lotman Yu. M.(1994) Conversations about Russian Culture. The Life and Traditions of Russian Nobility (XY111-the beginning of X1X century). S-P: "Art-SPB". $396 \mathrm{p}$.

Klyuchevsky V. O. (1989) The Course of Russian History. M.: "Mysll".Vol. 4.398 p.

Buldakov V. P. (2007)Quo vadis? Crises in Russia: Ways of Rethinking. Moscow: Russian political encyclopedia (ROSSPEN). 294p .

Berdyaev N.A.(1990) The Origins and Meaning of Russian Communism. M.Science. 224 p.

Buldakov V. P. (2012) Utopia, Aggression, Power. M.: ROSSPEN. 759 p.

Kharkhordin O. V. (2002)"To Denounce and be a Hypocrite".SPb.: Summer garden.211p.

Voslensky, M. S.(1990) Nomenclature. L. 664 p. 
Pivovarov Yu.S.(2006) Russian Politics in Its Historical and Cultural Relation. M. ROSSPEN.168 p.

Akhiezer A., Klyamkin I., Yakovenko I.(2013) Russian History: the End or a New Beginning? M. 496 p.

Kostomarov N. N.(1994) Russian Republic (North Russian People's Rights during the Specific-Veche Way of Life. The History of Novgorod, Pskov and Vyatka). M. "Charlie", Smolensk" Smyadyn".- 544 p.

Pivovarov Ju. S. (2014)The Russian Present and the Soviet Past. Center for Humanitarian Initiatives. M-S-P : University book.- $336 \mathrm{p}$.

Pervushina V. N.(2015) Ideology in Contemporary Russia. Bulletin of Voronezh state University. Philosophy Series. No. 2. 132-139.

Klyuchevsky V. O. (1988) Works in 9 volumes. M. Vol. 1. 414 p. 